Review

\title{
UV-Induced Cell Death in Plants
}

\section{Ganesh M. Nawkar ${ }^{\dagger}$, Punyakishore Maibam ${ }^{\dagger}$, Jung Hoon Park, Vaidurya Pratap Sahi, Sang Yeol Lee * and Chang Ho Kang *}

Division of Applied Life Sciences (BK21 program) and Plant Molecular Biology and Biotechnology Research Center, Gyeongsang National University, Jinju 660-701, Korea; E-Mails: ganeshtnau@gmail.com (G.M.N.); punya.maibam@gmail.com (P.M.); jazze@nate.com (J.H.P.); vpsahi@hotmail.com (V.P.S.)

$\dagger$ These authors contributed equally to this work.

* Authors to whom correspondence should be addressed; E-Mails: sylee@gnu.ac.kr (S.Y.L.); jacobgnu69@gnu.ac.kr (C.H.K.); Tel.: +82-55-772-1351 (S.Y.L.); +82-55-772-2639 (C.H.K.); Fax: +82-55-759-9363 (S.Y.L. \& C.H.K.).

Received: 1 November 2012; in revised form: 5 December 2012 / Accepted: 4 January 2013 / Published: 14 January 2013

\begin{abstract}
Plants are photosynthetic organisms that depend on sunlight for energy. Plants respond to light through different photoreceptors and show photomorphogenic development. Apart from Photosynthetically Active Radiation (PAR; 400-700 nm), plants are exposed to UV light, which is comprised of UV-C (below $280 \mathrm{~nm}$ ), UV-B $(280-320 \mathrm{~nm})$ and UV-A $(320-390 \mathrm{~nm})$. The atmospheric ozone layer protects UV-C radiation from reaching earth while the UVR8 protein acts as a receptor for UV-B radiation. Low levels of UV-B exposure initiate signaling through UVR8 and induce secondary metabolite genes involved in protection against UV while higher dosages are very detrimental to plants. It has also been reported that genes involved in MAPK cascade help the plant in providing tolerance against UV radiation. The important targets of UV radiation in plant cells are DNA, lipids and proteins and also vital processes such as photosynthesis. Recent studies showed that, in response to UV radiation, mitochondria and chloroplasts produce a reactive oxygen species (ROS). Arabidopsis metacaspase-8 (AtMC8) is induced in response to oxidative stress caused by ROS, which acts downstream of the radical induced cell death (AtRCD1) gene making plants vulnerable to cell death. The studies on salicylic and jasmonic acid signaling mutants revealed that SA and JA regulate the ROS level and antagonize ROS mediated cell death. Recently, molecular
\end{abstract}


studies have revealed genes involved in response to UV exposure, with respect to programmed cell death (PCD).

Keywords: UV radiation; reactive oxygen species (ROS); cell death

\section{Introduction}

Light energy from the sun and the ability of photoautotrophs to fix that energy in the presence of chlorophyll has promoted life on earth. Apart from being an energy source, light acts as a major environmental cue for plants to adjust to the surrounding conditions. In nature, solar radiation comprises different wavelengths of electromagnetic radiation and is broadly classified as Ultraviolet Radiation (UV $<400 \mathrm{~nm}$ ), Photosynthetically Active Radiation (PAR 400-700 nm) and Far Red Radiation (FR 700-780 nm). Approximately 7\%-9\% of the total solar radiation reaching the earth's surface is in the UV range $(200-400 \mathrm{~nm})$ [1-4]. UV radiation is broadly classified based on wavelength as UV-C radiation $(200-280 \mathrm{~nm})$, which is the most hazardous range of UV light but physiologically insignificant since these wavelengths are completely absorbed by the atmosphere; UV-B radiation (280-320 nm), which is filtered through the stratospheric ozone layer and, therefore, only a small proportion reaches the earth surface; and UV-A radiation (320-400 nm), which cannot be absorbed by the ozone layer and is fully transmitted to the earth's surface. Among these three types of UV radiation, UV-B is of prime importance despite its small proportion i.e., 1.5\% of total radiation, because of its severe damaging effects on plant growth and development. UV-A radiation, although it represents $6.3 \%$ of total radiation, is less harmful than the other wavelengths of UV radiation [3].

The flux of solar radiation is strongly modified when transmitted through the earth's atmosphere and it greatly varies due to different factors like solar angle (time of the day, season, latitude), altitude, stratospheric ozone, cloud cover and shading [5,6]. The ozone layer acts as a key component protecting living beings from the damaging UV radiation. Anthropogenic factors, such as the release of chlorofluorocarbons into the atmosphere, can result in a depletion of the ozone layer of 5\% [7]. In general, a $1 \%$ reduction in the ozone layer results in a $1.3 \%-1.8 \%$ increase in the amount of biologically active UV-B radiation [3]. The adoption of the international Montreal Protocol, which seeks to reduce factors that deplete the ozone layer, is a possible solution to this complex problem. Despite such efforts, the global ozone level is still lower than in the 1970s and a return to that state is not expected for several decades [8]. Moreover, there has been a significant increase in UV-B radiation reaching the earth's surface between 1979 and 2008, over all latitudes except the equatorial zone, with the largest increments taking place at mid to high latitudes in the Southern Hemisphere $[9,10]$. Thus, this scenario of changing climate suggests that life on earth will be continuously exposed to higher dosages of UV radiation. It is therefore important to study in detail the effect of UV radiation on plants.

The current knowledge regarding ecophysiological impact of UV radiation on plants has come largely through field experiments using natural or moderately higher levels of UV-B radiation. The results from all these experiments can be summarized as UV-B radiation has very small $(<20 \%)$ inhibitory effect on plant growth, on activation of acclimation response and on interference between the interaction of plants and herbivores [11-13]. Apart from field condition experiments, data from 
laboratory controlled conditions has helped us in the understanding of UV-B perception, signaling and UV induced damage. It has been documented that plants respond differentially to UV fluence rate as well as wavelength $[4,14]$. Lower doses of UV-B stimulate photomorphogenesis in etiolated plants while higher doses of UV-B or UV-C result in cellular damage [4,15]. It has been reported that UV-C overexposure can induce programmed cell death (PCD) by activation of caspase-like proteases, oligonucleosomal DNA fragmentation, and appearance of apoptotic nuclear morphology in Arabidopsis thaliana [16-18]. Moreover, UV-B overexposure can also induce PCD in a BY-2 tobacco cell line [19]. The current review focuses on the detailed mechanism of PCD in response to higher UV radiation and its physiological significance.

\section{Perception and Signaling of UV Light in Plants}

Light regulates different growth stages and vital physiological process throughout the lifecycle of plants. Owing to the importance of light, plants evolved different photoreceptors for perception of light through which they can sense the quality (wavelength), intensity, duration (including day length) and direction of light [20]. Plants have evolved complex and sophisticated transcriptional networks involving different photoreceptors that mediate developmental changes in response to light. These developmental changes, which include seed germination, de-etiolation, gravitropic orientation, plant architecture, stomatal movement and reproductive development at time of flowering, have been extensively reviewed [21-23]. In Arabidopsis, three classes of UV-A/blue photoreceptors viz., cryptochromes (CRY1, CRY2 and CRY3), phototropins (PHOT1, PHOT2) and members of the Zeitlupe family (ZTL, FKF1, and LKP2) [24-27] have been identified, while red (R) and far-red (FR) light is maximally absorbed by the phytochromes (PHYA, PHYB, PHYC, PHYD and PHYE) [28,29]. Different studies have shown that UV-B radiation evokes diverse phenotypic responses, including hypocotyl growth inhibition, cotyledon expansion, phototropic curvature and induction of UV-B-protecting pigmentation, in plants [15,30-34]. In the last decade, whole genome expression profiling has identified specific pathways activated in response to low-level UV-B [35]. These photomorphogenic UV-B responses have been shown to be mediated through UV RESISTANCE LOCUS8 (UVR8) protein [20,34,36] which has been characterized as a UV-B photoreceptor [37-39]. UVR8 is a $\beta$-propeller protein showing similarity with human guanine nucleotide exchange factor Regulator of Chromatin Condensation 1 (RCC1) and its crystal structure is maintained by salt bridge interactions between charged amino acids Arg, Asp and Glu at the dimeric interaction surface [38]. Four tryptophans (W94, W233, W285, and W337) located adjacent to salt-bridge amino acids are arranged to form two pyramids across the dimeric interface [38]. Absorption of UV-B light by one or more tryptophans results in a loss of excitation coupling and leads to disruption of salt-bridges and hence monomerization. Unlike other photoreceptors UVR8 lacks a specific chromophore or rather intrinsic tryptophans W285 and W233 which are important for UV-B absorbance [38,39].

Interestingly, the UV-B specific pathway is devoid of known light photoreceptors but involves two known central components of light signaling, viz., ELONGATED HYPOCOTYL (HY5) and CONSTITUTIVE PHOTOMORPHOGENESIS 1 (COP1). The UVR8 interacts with COP1 in UV-B dependant manner to activate expression of a set of genes that protects against potential damage by UV-B exposure, including genes encoding flavonoid biosynthesis enzymes, DNA repair enzymes, and 
also proteins involved in mitigating oxidative stress as shown in Figure 1 [34]. The downstream components in the UVR8-COP1-HY5 pathways are summarized in Table 1.

The importance of UVR8 mediated response in the acclimatization of plants against UV-B radiation is well known from the fact that the Arabidopsis mutant does not accumulate flavanoids and other phenolic compounds showing that they are UV sensitive. It was reported that flavanoids also possess free-radical scavenging activity that might offer additional cellular protection [40]. Apart from induction of UV absorbing pigments, there is upregulation of DNA repair machineries such as photolyase genes. The summary of genes impaired in UV sunscreen pigments causing hyper or hypo- sensitivity to UV radiation is given in Table 2 .

Figure 1. Low-fluence UV radiation activates UVR8 dependent photomorphogenesis. A, Increased level of UV-absorbing sunscreens gives acclimation response; B, Increased anti-oxidative proteins can act as ROS scavengers; C, Increased level of DNA repair enzymes can act on CPDs and 6-6 PPs lesions and may result in cell cycle arrest and overall growth inhibition.

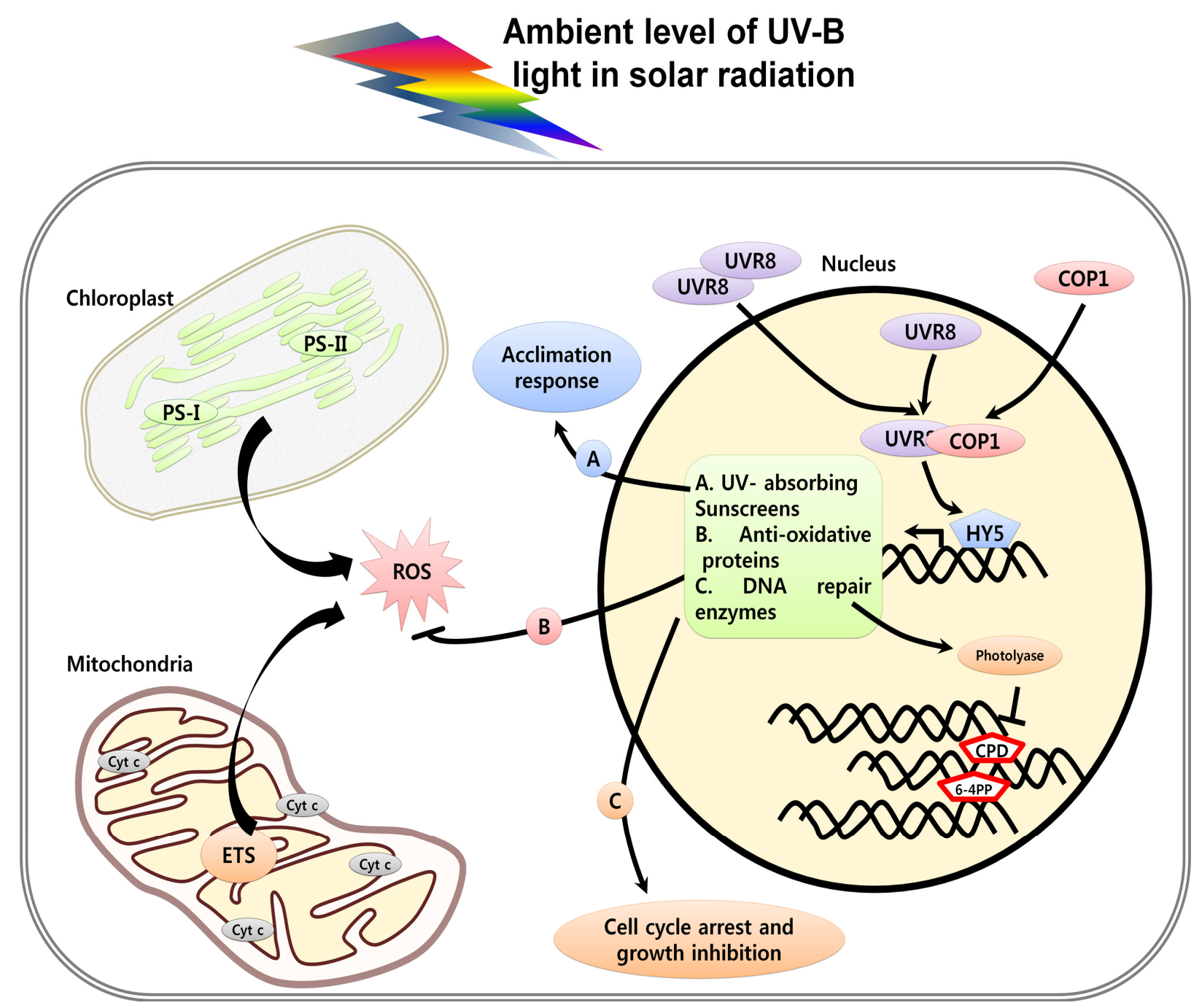


Table 1. List of genes involved in UV-B light perception, signaling and stress pathway.

\begin{tabular}{|c|c|c|c|c|}
\hline Symbol & AGI code & Full name & Phenotype of UV-grown mutant seedlings & Reference \\
\hline UVR8 & AT5G63860 & UVB-RESISTANCE 8 & $\begin{array}{l}\text { hypersensitive to UV-B and blocks expression } \\
\text { of UV-B induced genes, acts as a UV-B } \\
\text { photoreceptor }\end{array}$ & {$[35,37,41]$} \\
\hline COP1 & AT2G32950 & $\begin{array}{l}\text { CONSTITUTIVE } \\
\text { PHOTOMORPHOGENIC } 1\end{array}$ & $\begin{array}{l}\text { hypersensitive to UV-B and blocks } \\
\text { UVR8-dependent expression of UV-B } \\
\text { induced genes }\end{array}$ & [42] \\
\hline HY5 & AT5G11260 & ELONGATED HYPOCOTYL 5 & $\begin{array}{l}\text { hypersensitive to UV-B and blocks } \\
\text { UVR8-COP1 dependent expression of } \\
\text { chalcone synthase and flavonoid } \\
\text { synthase pathway }\end{array}$ & [14] \\
\hline$H Y H$ & AT3G17609 & HY5-HOMOLOG & $\begin{array}{l}\text { hypersensitive to UV-B and showed } \\
\text { overlapping functions with HY5 in affecting } \\
\text { UV-B induced gene expression }\end{array}$ & [43] \\
\hline$B B X 24$ & AT1G06040 & B-BOX DOMAIN PROTEIN 24 & $\begin{array}{l}\text { hypersensitive to UV-B and BBX24 interacts } \\
\text { with COP1 and antagonizes the transcriptional } \\
\text { activity of HY5 in response to UV-B }\end{array}$ & [44] \\
\hline$R U P 1$ & AT5G52250 & $\begin{array}{l}\text { REPRESSOR OF UV-B } \\
\text { PHOTOMORPHOGENESIS } 1\end{array}$ & $\begin{array}{l}\text { no obvious phenotype but acts redundantly to } \\
\text { RUP2. The double rup1rup } 2 \text { mutant is } \\
\text { hypersensitive to UV-B }\end{array}$ & [45] \\
\hline RUP2 & AT5G23730 & $\begin{array}{l}\text { REPRESSOR OF UV-B } \\
\text { PHOTOMORPHOGENESIS } 2\end{array}$ & $\begin{array}{l}\text { hypersensitive to UV-B and acts in feedback } \\
\text { regulation of UV signaling }\end{array}$ & [45] \\
\hline$M K P 1$ & AT1G10210 & $\begin{array}{l}\text { MITOGEN-ACTIVATED } \\
\text { PROTEIN KINASE } 1 \\
\end{array}$ & $\begin{array}{l}\text { mutant is hypersensitive to acute UV-B stress } \\
\text { due to mis-regulation of MPK } 3 \text { and MPK6 }\end{array}$ & [46] \\
\hline$M P K 3$ & AT3G45640 & $\begin{array}{l}\text { MITOGEN-ACTIVATED } \\
\text { PROTEIN KINASE } 3\end{array}$ & \multirow{2}{*}{$\begin{array}{l}\text { mutants display increased tolerance to UV-B } \\
\text { radiation }\end{array}$} & \multirow{2}{*}{ [46] } \\
\hline MPK6 & AT2G43790 & $\begin{array}{l}\text { MITOGEN-ACTIVATED } \\
\text { PROTEIN KINASE } 6\end{array}$ & & \\
\hline
\end{tabular}

Table 2. List of genes showing hyper or hypo- sensitivity to UV-B light.

\begin{tabular}{|c|c|c|c|c|}
\hline Symbol & AGI code & Full name & Phenotype of UV-grown mutant seedlings & Reference \\
\hline TT4 & AT5G13930 & $\begin{array}{l}\text { TRANSPARENT TESTA 4/ } \\
\text { CHALCONE SYNTHASE }\end{array}$ & $\begin{array}{l}\text { has reduced flavonoids and normal levels of } \\
\text { sinapate esters, is more sensitive to UV-B }\end{array}$ & [47] \\
\hline TT5 & AT3G55120 & $\begin{array}{l}\text { TRANSPARENT TESTA 5/ } \\
\text { CHALCONE ISOMERASE }\end{array}$ & $\begin{array}{l}\text { has reduced levels of UV-absorptive leaf } \\
\text { flavonoids and the monocyclic sinapic acid } \\
\text { ester phenolic compounds, are highly sensitive } \\
\text { to UV-B }\end{array}$ & [47] \\
\hline TT6 & AT3G51240 & $\begin{array}{l}\text { TRANSPARENT TESTA 6/ } \\
\text { FLAVANONE } 3 \\
\text { HYDROXYLASE }\end{array}$ & $\begin{array}{l}\text { similar to } t t 5 \text {, mutants are highly sensitive to } \\
\text { UV-B light damage }\end{array}$ & [47] \\
\hline$P F G 1$ & AT2G47460 & $\begin{array}{l}\text { PRODUCTION OF FLAVONOL } \\
\text { GLYCOSIDES } 1\end{array}$ & $\begin{array}{l}\text { acts downstream of HY5 and overexpression } \\
\text { is sufficient to increase UV-B tolerance }\end{array}$ & [48] \\
\hline$P F G 2$ & AT3G62610 & $\begin{array}{l}\text { PRODUCTION OF FLAVONOL } \\
\text { GLYCOSIDES } 2\end{array}$ & $\begin{array}{l}\text { hypersensitive to UV-B due to low levels of } \\
\text { flavonol compounds } n \text { response to UV-B }\end{array}$ & [48] \\
\hline
\end{tabular}


Table 2. Cont.

\begin{tabular}{|c|c|c|c|c|}
\hline Symbol & AGI code & Full name & Phenotype of UV-grown mutant seedlings & Reference \\
\hline $\mathrm{HOl}$ & AT2G26670 & HEME OXYGENASE 1 & $\begin{array}{l}\text { hypersensitive to UV-C due to down } \\
\text { regulation of flavonoid and carotenoid } \\
\text { metabolism as well as antioxidant defense } \\
\text { mechanisms }\end{array}$ & [49] \\
\hline$U L I 3$ & AT5G59920 & UV-B LIGHT INSENSITIVE 3 & $\begin{array}{l}\text { mutant is hyposensitive to UV-B and affected } \\
\text { in its hypocotyls elongation but was also } \\
\text { impaired in CHS and PR-1gene expression } \\
\text { after irradiation with continuous UV-B }\end{array}$ & {$[15]$} \\
\hline
\end{tabular}

Figure 2. High-fluence UV radiation activates UVR8 independent stress pathway and cell death. A, Stress from UV exposure activates the mitogen-activated protein kinases (MAPK) cascade which leads to regulation of PCD; B, ROS released from chloroplast and mitochondria causes membrane lipid and protein oxidation, Mitochondrial Transmembrane Potential (MTP) loss from mitochondria results in cytochrome c release and activation of caspases and finally DNA laddering; C, High UV stress leads to A and B, which result in cell shrinkage, nuclear condensation showing Apoptotic like-PCD (AL-PCD). * Dotted arrow indicates the stress response pathway activated by yet unknown UV photoreceptor; "?" indicates the unknown UV photoreceptor, obscure role of UVR8 dependant pathway under stress conditions and the mechanistic involvement of AtDAD1, AtDAD2 and AtBI in UV induced PCD is unclear.

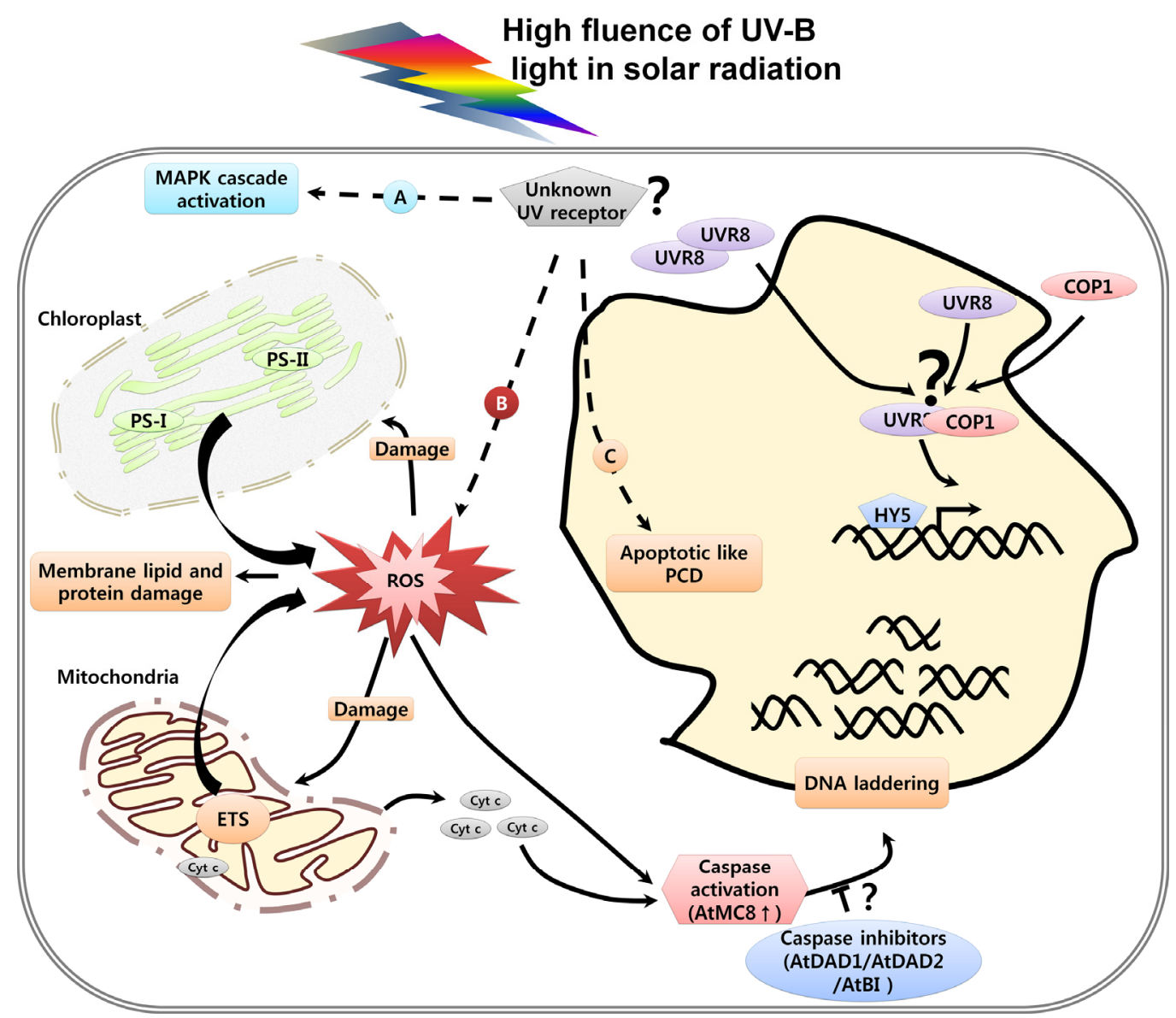


Although, in the last decade we have made much progress regarding the understanding of the UV-B photoreceptor and its structure in the model plant Arabidopsis, there are still certain points to be considered. The fluence response curve experiment with $u v r 8-2$ and hy5 lines in etiolated plants does not show significant differences from the wild type suggesting the presence of some other photoreceptors in plants [50]. It has been speculated that longer wavelengths and shorter wavelengths of UV-B radiation trigger two pathways and the shorter wavelength pathway negatively interferes with the longer wavelength pathway. The longer wavelength response can be mediated by UV-B photoreceptors and the short wavelength may represent indirect effects of UV-B exposure through general cellular stress pathways or distinct photoreceptors [14,50]. Due to the lack of well-defined phenotypes and the accompanying damage caused by UV-B it has made it difficult to determine a UV-B photoreceptor apart from UVR8 which can respond to short wavelength radiation and regulate stress response. The UV-B induced stress pathway also known as "UV response", is conserved in yeast, mammals and plants and involves the activation of mitogen-activated protein kinases (MAPKs) [51-53]. Recently, in Arabidopsis, MPK3 and MPK6 have been shown to be activated in response to UV-B stress and their mis-regulation in $m k p 1$ mutant results in UV-B hypersensitivity phenotypes [46]. The MPK6 has been known as a positive regulator of programmed cell death (PCD) in developmental processes like senescence [54,55] and also in biotic stresses like pathogen attacks [56]. Thus, it has been suggested that MKP1 provides protection against UV-B-induced cell death by inhibiting UV-induced MPK3 and MPK6 activities [46]. The two UV-B response pathways namely UV-B induced photomorphogenesis regulated by UVR8 and stress induced MAPK pathway have been shown to be independent of each other and coordinately determine plant UV-B tolerance (Figure 2).

\section{UV Induced Damage and Cell Death}

Recently the UV-B light specific photoreceptors were reviewed and it was explained there how low fluence UV-B induces protective response [20]. In the current review, we discuss in detail UV light perception, signaling and important UV targets in the cell with a focus on how high intensity UV induces plant stress. The response to such stress independent of the UV photoreceptor and plants can activate the cell death pathway. Programmed cell death (PCD), is a genetically controlled self destruction mechanism in all eukaryotic multi-cellular organisms, and can be induced either as part of normal development or in response to stress. PCD is also known as apoptosis and has been well studied in animal systems. Apoptosis is characterized by specific hallmarks such as cell shrinkage, nuclear condensation and fragmentation, and eventually the breakup of the cell into "apoptotic bodies" that are eventually engulfed by phagocytes [57,58]. The progress of plant PCD is much slower but interestingly shares many conserved components with animal apoptosis. Despite the similarities between cell death pathways in plants and animals, there is no evidence for apoptotic bodies, as well as classical caspases in plant systems. Plant cell death is described as an apoptotic-like PCD (AL-PCD) [59]. AL-PCD is now accepted as a fundamental cellular process since it plays an essential role during development, under stress conditions, in the senescence process and in response to pathogen infection in plants [60,61]. Apart from developmental stimuli, biotic stresses, such as the pathogen induced hypersensitivity response (HR) and abiotic stresses such as heat stress and high fluence UV radiation, 
have been shown to induce AL-PCD [16,62-65]. Genes involved in cell death pathway in plants in response to UV radiation are summarized in Table 3.

Table 3. List of genes involved in cell death pathway in plants in response to UV radiation.

\begin{tabular}{|c|c|c|c|c|}
\hline Symbol & AGI code & Full name & Effect on UV-induced cell death & Reference \\
\hline$A t D A D 1$ & AT1G32210 & $\begin{array}{l}\text { DEFENDER AGAINST } \\
\text { APOPTOTIC DEATH } 1\end{array}$ & \multirow{2}{*}{$\begin{array}{l}\text { overexpression can suppress the DNA } \\
\text { fragmentation caused by DEVDase activity and } \\
\text { retard UV-B induced cell death }\end{array}$} & \multirow{2}{*}[17]{} \\
\hline$A t D A D 2$ & AT2G35520 & $\begin{array}{l}\text { DEFENDER AGAINST } \\
\text { CELL DEATH } 2 \text { (DAD2) }\end{array}$ & & \\
\hline$A t B I$ & AT5G47120 & BAX INHIBITOR 1 & $\begin{array}{l}\text { anti-apoptotic protein increases cell survivability } \\
\text { under abiotic stresses }\end{array}$ & {$[66]$} \\
\hline AtMC8 & AT1G16420 & METACASPASE 8 & $\begin{array}{l}\text { induced in response to UV-C radiation and induces } \\
\text { cell death since knock out mutant is tolerant }\end{array}$ & [67] \\
\hline$R C D 1$ & AT1G32230 & $\begin{array}{l}\text { RADICAL-INDUCED } \\
\text { CELL DEATH1 }\end{array}$ & $\begin{array}{l}\text { mutants are sensitive to ozone and apoplastic } \\
\text { superoxides but tolerant to ROS and UV-B stress }\end{array}$ & {$[67,68]$} \\
\hline
\end{tabular}

\subsection{DNA Damage, Cell Cycle Arrest and Cell Death}

DNA is one of the key targets for UV-induced damage in both prokaryotic and eukaryotic cells. The adverse effects of solar radiation on living organisms are mostly due to the small amount of UV-B reaching the earth's surface that is absorbed by cellular DNA. UV-A wavelengths are less efficient in inducing DNA damage as they are not absorbed by native DNA. It has been documented that the increase in solar UV-B radiation, due to a long-term depletion of the stratospheric ozone layer, may influence the genomic stability of plant populations [69]. The different types of DNA damage in response to UV-B or UV-C radiation includes the formation of cyclobutyl pyrimidine dimers (CPDs), (6-4) photoproducts ((6-4) PPs) [70], Inter/Intra Cross Link (ICL), 8-oxoG or even DNA Double-Strand Breaks (DSBs) [71]. The formation of CPDs represents approximately $75 \%$ of the total DNA damage by UV light [70]. The plants adopt three different strategies towards minimizing the DNA damage namely plant-specific photo reactivation pathway [70], global genome repair- nucleotide excision repair (GGR-NER) pathway [71,72] and homologous recombination [73]. The photo reactivation pathway includes different photolyases for example in Arabidopsis, the UVR2 gene encodes a photolyase (PHR1) that acts only on CPDs [74] whereas the UVR3 gene encodes a photolyase specific for 6-4 photoproducts [75]. CPDs and 6-4 PPs can also be removed in the dark through nucleotide excision repair, endonucleolytic cleavage, release of the damaged nucleotides and strand re-synthesis [72]. The genes mentioned above involved in DNA repair pathways are summarized in Table 4.

In mammals, it has been reported that DNA damage caused by UV radiation results in cell cycle arrest and apoptosis [76] but very little is known about such mechanisms in plants. The transcriptional responses of maize to UV-B radiation under field conditions indicates that UV-B might affect the cell cycle [77]. Recently, it has been shown that UV-B radiation modulates cell cycle regulatory genes involved in G1 -to- S transition using HU (Hydroxy Urea) synchronized root tips of Arabidopsis. The delayed induction of $C Y C D 3 ; 1$ transcripts under UV-B radiation results in delayed G1-to-S transition [78]. It was also confirmed that the G1-to-S arrest induced by UV-B in root tips was a consequence of DNA damage which has been shown using uvhl mutant impaired in removal of CPDs [78,79]. 
G1-to-S arrest induced by UV-B has been suggested as a protective mechanism against UV-B-induced DNA damage, which allows time for repairing DNA damages before replication. This study concludes that the DNA damage is a possible reason behind the plant growth inhibition after UV exposure. In Arabidopsis, there are two proteins which can acts as sensors of DNA damage, namely, ATM (ataxia-telangiectasia mutated) and ATR (ataxia-telangiectasia and Rad3-related). The role of Arabidopsis ATM is more prominent under gamma radiation induced DNA damage while ATR deficient plants showed hypersensitivity to UV-B radiation and exhibited altered G2-phase cell cycle checkpoints [80,81]. Different genes involved in cell cycle regulation impairment causing UV-induced hypersensitivity response are summarized in Table 4.

Table 4. List of genes involved in plant DNA repair mechanism, cell cycle regulation and programmed cell death (PCD) in response to UV radiation.

\begin{tabular}{|c|c|c|c|c|}
\hline Symbol & AGI code & Full name & $\begin{array}{l}\text { Phenotype of UV-grown } \\
\text { mutant seedlings }\end{array}$ & Reference \\
\hline UVR2/PHR 1 & AT1G12370 & $\begin{array}{l}\text { UV REPAIR DEFECTIVE 2/ } \\
\text { PHOTOLYASE } 1\end{array}$ & $\begin{array}{l}\text { mutant is impaired in the CPD } \\
\text { photolyase gene } P H R 1 \text { and thus, } \\
\text { hypersensitive to high doses of UV-B }\end{array}$ & {$[82]$} \\
\hline UVR3 & AT3G15620 & UV REPAIR DEFECTIVE 3 & $\begin{array}{l}\text { mutant is hypersensitive to high doses } \\
\text { of UV-B as it is defective in } \\
\text { photoreactivation of } 6-4 \text { photoproducts }\end{array}$ & {$[75]$} \\
\hline UVR1/UVH1 & AT3G28030 & UV REPAIR DEFECTIVE 1 & $\begin{array}{l}\text { mutants are defective in dark repair or } \\
\text { Nucleotide Excision Repair and shows } \\
\text { hypersensitive to UV radiation }\end{array}$ & {$[72]$} \\
\hline CEN2 & AT4G37010 & CENTRIN 2 & $\begin{array}{l}\text { mutants exhibited a moderate UV-C } \\
\text { sensitivity due to defective } \\
\text { Homologous Recombination and } \\
\text { Nucleotide Excision Repair }\end{array}$ & {$[83]$} \\
\hline$A T R$ & AT5G40820 & $\begin{array}{l}\text { ATAXIA } \\
\text { TELANGIECTASIA-MUTATED } \\
\text { AND RAD3-RELATED }\end{array}$ & $\begin{array}{l}\text { mutants is defective in cell-cycle arrest } \\
\text { in response to DNA damage, and this } \\
\text { causes elevated cell death under high } \\
\text { level of UV-B }\end{array}$ & {$[80]$} \\
\hline ATM & AT3G48190 & $\begin{array}{l}\text { ATAXIA-TELANGIECTASIA } \\
\text { MUTATED }\end{array}$ & $\begin{array}{l}\text { mutants show elevated cell death under } \\
\text { high level UV-B due to DNA damage }\end{array}$ & {$[84]$} \\
\hline SOG1 & AT1G25580 & $\begin{array}{l}\text { SUPPRESSOR OF GAMMA } \\
\text { RADIATION } 1\end{array}$ & $\begin{array}{l}\text { mutant show reduced PCD in response } \\
\text { to UV-B induced DNA photoproducts }\end{array}$ & {$[84]$} \\
\hline$S U V 2$ & AT5G45610 & SENSITIVE TO UV 2 & $\begin{array}{l}\text { mutant is UV-B sensitive which has a } \\
\text { weaker expression of } C Y C B 1 ; 1 \text { in } \\
\text { response to DNA damage }\end{array}$ & [85] \\
\hline
\end{tabular}

The higher doses of UV-B or UV-C radiation can induce oligonucleosomal DNA fragmentation, as a physiological response, which shows nucleosomal fragments in multiples of $180 \mathrm{bp}$ like a typical apoptotic DNA ladder [16,19]. DNA laddering is an integral part of programmed cell death (PCD) in plant systems [86,87], confirming the role of UV radiation in induction of PCD. DNA damage is quantified by using terminal deoxynucleotidyl transferase-mediated dUTP nick-end labeling reaction (TUNEL), which detects in situ free 3'-OH DNA breaks [16,88]. Although the doses of UV radiation 
in the above mentioned studies are physiologically irrelevant, they are still important for making experimental set ups to study PCD responses in plants.

\subsection{Proteins and Lipids Damage}

Proteins and lipids are direct targets of UV-B radiation. Since proteins strongly absorb $\sim 280 \mathrm{~nm}$ or higher wavelengths, UV-B can affect the aromatic amino acids such as tyrosine, phenylalanine, and tryptophan [89]. Proteins can undergo photomodification directly through photooxidation reactions or indirectly by photosensitized production of active oxygen species and free radicals. UV-B exposures lead to damage of photosynthetic machinery including RUBISCO [90]. These direct effects are often observed in high UV-B fluence and low accompanying PAR. However, the induced loss of photosynthetic activity, often observed under lab or greenhouse conditions might not translate to the fields or natural conditions [91]. UV-B damages the ribosomes by crosslinking with the cytosolic ribosomal proteins and chloroplast ribosomal proteins to RNA, thereby transiently inhibiting translation in vivo. Although there is a small and significant decline in photosynthesis rate, recovery is complete by the next day and also there are no changes in the levels of chlorophylls a and b, carotenoids, or total proteins [92]. Thus, despite the presence of ribosome damage and a decrease in translation, physiological parameters were not significantly affected by the UV-B treatments, demonstrating that the treatment applied was not lethal.

Plant cell membranes contain unsaturated fatty acids, which are damaged by UV-radiation in the presence of oxygen $[93,94]$. The peroxidation of membrane lipids leads to breakdown of their structure and function $[95,96]$. The composition of membrane lipids such as mono- and digalactosyldiglicerides (MGDGs, DGDGs) in chloroplasts may change due to UV-radiation. The concentration of the MGDGs reduced without affecting the overall DGDG concentration and the total phospholipid levels. This reduction of the MGDGs is important for maintaining the optimal membrane structure in chloroplasts for photosynthesis under UV-B radiation [97].

\subsection{Organelle Dysfunction in Response to UV and Cell Death}

In plants, chloroplast and mitochondria are the two important cell organelles which act as sites of ROS production (Figure 2). Plant chloroplasts capture light energy during photosynthesis, a process that is very sensitive to stress conditions generating ROS or oxidative damage $[98,99]$. It is known that chloroplasts are involved in different cell death processes such as leaf senescence [100]. Chloroplast involvement in PCD was confirmed by ectopic expression of mammalian anti-apoptotic Bcl-2 family members, which protect transgenic tobacco plants from PCD, induced by chloroplast-targeted herbicides [101]. The chloroplast specific ROS inhibitor 3-(3,4-dichlorophenyl1)-1,1-dimethylurea (DCMU) can retard cell death induced in response to UV overexposure. Moreover, after UV treatment and under continuous light, ROS, derived from chloroplasts, may further damage adjacent mitochondria [18].

Involvement of mitochondria in programmed cell death has been extensively studied in animals. Recently, a role for mitochondria in plant PCD was reported in response to different stimuli such as ceramide, protoporphyrin IX, the HR elicitor AvrRpt2, and UV-C radiation [18,102]. Different stress conditions cause changes of the mitochondrial transmembrane potential (MTP) releasing cytochrome $\mathrm{c}$ 
into the intermembrane mitochondrial space, which activates caspase activity and subsequently cell death $[102,103]$.

\subsection{UV-Induced Caspase Activity and Cell Death}

In the animal systems, apoptotic cell death is controlled by caspases (cysteine-dependent aspartate-specific proteases), which show specific protease activity upon induction by cell death [104,105]. In plants, caspase-like activities have been demonstrated during hypersensitive response (HR) [106] or after heat shock of suspension cells [107]. However, plants do not appear to have true caspases but rather a small family of proteins that share similarities with caspase-like domains, known as metacaspases [108]. There are nine metacaspases genes in the Arabidopsis genome, which can be divided into two types. Type I is comprised of three genes, while the Type II subfamily consists of six genes. Among these nine metacaspases, five genes prefer arginine rather than aspartate as a P1 amino acid at the cleavage site [109-111]. It has been hypothesized that the metacaspases are the functional homologs of animal caspases in plants.

A protease, cleaving the caspase substrate Asp-Glu-Val-Asp (DEVDase activity), is induced within $30 \mathrm{~min}$ and peaks at $1 \mathrm{~h}$ by UV overexposure under light conditions [17]. Broad-range cysteine protease inhibitors did not affect the DEVDase activity. However, caspase-1 and caspase-3 inhibitors and the pan-caspase inhibitor p35 were able to block this activity. Strong, ectopic expression of AtDAD1 and AtDAD2, A. thaliana homologs of Defender against Apoptotic Death-1, can suppress the DNA fragmentation caused by DEVDase activity and, in turn increase cell survivability under stress conditions (Figure 2). The activation of caspase-3-like protease in UV-C-induced PCD has been documented using FRET technique which is a powerful tool for monitoring key events of PCD in living cells [112]. These data confirm that the caspase-like activities observed during HR, heat stress and UV exposure function in a similar manner to animal caspases. Apart from this indirect evidence, it has been demonstrated that there is induction of Arabidopsis metacaspase-8 (AtMC8), in response to oxidative stresses caused by UV-C, $\mathrm{H}_{2} \mathrm{O}_{2}$, or methyl viologen [67]. The induction of AtMC8 depends on AtRCD1 and thus, mutant defective in either atmc8-1/2 or $r c d 1-1$ lines display tolerance to cell death induced by ultraviolet light. Interestingly, the induction of AtMC 8 transcripts in response to UV treatments also depends upon light showing it to be an integral part of plant specific PCD. However, it is not clear how light promotes cell death in response to stress.

\subsection{UV-Induced ROS and Cell Death}

In plants, ROS are generated as byproducts of essential energy generating processes such as photosynthesis and respiration. Therefore, some ROS production by chloroplasts and mitochondria is an unavoidable incidence in plants [113-115]. It was demonstrated that ROS are induced in response to different biotic and abiotic stresses. Recently, in addition to being a cell damaging agent, ROS were described as secondary signaling molecules [116]. ROS-mediated signaling is a complex mechanism that depends on the nature of the individual ROS species produced, the balance between ROS producing enzymes, and the oxidation-reduction states of various antioxidants [117]. Plants show elevated levels of ROS due to disruption of metabolic activities and increased activity of membrane-localized NADPH-oxidase in response to UV radiation [118,119]. High UV-B radiation 
exposure to plants causes conditions similar to oxidative stress resulting from ROS and the gene expression pattern exhibited under both conditions is similar [120]. UVR8 mediated acclimatization is important for the survival of the plant against oxidative stress caused by UV- B radiation.

The defense responses to various pathogenic attacks [121] and other unfavorable conditions fails to control excess ROS accumulation leading to oxidative stress and may lead to cell death. Recently, the role of ROS as a trigger of UV-induced cell death processes in plants was studied. ROS acts as a signaling molecule leading to the opening of the permeability transition pore (PTP) in the mitochondrial membrane, which leads to the release of cytochrome $\mathrm{c}$ and the generation of more ROS, causing a feedback loop that amplifies the original PCD-inducing stress signal [58,122]. ROS-dependent release of cyrochrome $\mathrm{c}$ from mitochondria during heat stress in tobacco cells suggested that the mitochondria may play a similar function in PCD in both plants and animals [123]. The role of mitochondria in the early stages of PCD induced by UV-C overexposure was confirmed using a protoplast system [18]. It was reported that before the onset of cell death, there was a loss of mitochondrial transmembrane potential (MTP). Subsequently, the mitochondria were found irregularly clumped around chloroplasts or aggregates in other places within the cytoplasm culminating in a loss of cellular movement of the mitochondria. The addition of cyclosporine, a known inhibitor of mitochondrial permeability transition pores (MPTP), effectively reduced the loss of MTP and in turn repressed cell death [18].

There are also roles for ROS and phytohormones [salicylic acid (SA), jasmonic acid (JA) and ethylene] in plant PCD [124]. In plants, the exposure to UV radiation results in transcriptional activation and repression of specific sets of genes. These regulatory pathways share common components involved in oxidative stress responses to pathogen attack, ozone exposure and wounding, including the involvement of ROS, SA, JA and ethylene. In response to UV-B exposure, SA levels increase, which triggers the induction of various pathogenesis related (PR) genes. Transgenic plants expressing $N a h G$, a bacterial enzyme that degrades salicylate to catechol, have significantly lower levels of SA with a concomitant reduction in the expression of $P R 1$ after UV-B exposure. These transgenic lines show increased sensitivity towards UV-B radiation $[125,126]$. In field conditions, UV-B radiation does not induces JA levels but increases tissue sensitivity towards JA. UV-B induces the accumulation of phenolic compounds using jasmonate-dependent (polyamine conjugates) and jasmonate-independent (flavonoids and chlorogenic acid) pathways mediated by UVR8 [127,128]. The JA insensitive mutant jarl is defective in the recovery from UV-B treatment indicating that JA is important for tolerance to UV radiation [127,129]. Like SA and JA, ethylene is also induced in response to diverse external stresses such as drought, ozone exposure and UV-B [97]. Although, ethylene is not required for induction of $P R l$ gene expression in response to pathogen infection, the ethylene insensitive mutant etrl was unable to induce $P R 1$ and $P D F 1.2$ gene expression in response to UV-B radiation [130].

\section{Conclusions}

Global warming coupled with ozone depletion has been reported to affect the growth and development of plants negatively. The amount of damage in plants may vary depending on other environmental factors like temperature, $\mathrm{CO}_{2}$ level, available nitrogen and altered precipitation. A 
breakthrough discovery in the field of UV perception and signaling was the identification of UVR8 as a photoreceptor for UV light and UV defense responses mediated by UVR8-COP1-HY5 pathway, which increases sunscreen pigments and ROS scavenging activity upon ambient levels of UV exposure. UV-B radiation induces DNA damage resulting in cell cycle arrest and may lead to cell death. The use of higher dosage of UV-B or UV-C radiation which is physiologically irrelevant can induce PCD in plants under laboratory conditions. The stress pathway activated under high fluence UV-B radiation is independent of UVR8 signaling. UV overexposure induces oxidative burst and subsequently disrupts the function of the vital organelles, chloroplast and mitochondria. Loss of mitochondrial transmembrane potential (MTP), causes the release of cytochrome c and, in turn, activates the metacaspase cascade in plants. Plant PCD is inhibited under dark conditions suggesting that light requirement is a plant specific character of PCD, but the exact role is unknown. Different anti-apoptotic genes like $A t D A D 1, A t D A D 2$ and $A t B I$ were shown to inhibit PCD but the direct evidence for their mechanistic involvement in UV specific cell death is lacking. Moreover, how the UV photoreceptor is involved in UV mediated cell death is not yet clear. In order to answer the questions raised above, it will be important to study the effect of UV signaling components of the cell death pathways under conditions of high fluence UV radiation.

\section{Acknowledgments}

This work was supported by grants from the Next-Generation BioGreen 21 Program (SSAC, grant \#: PJ009068032012) and the Basic Science Research Program through the National Research Foundation of Korea (NRF) funded by the Ministry of Education, Science and Technology (grant \#: 2012R1A1A2044337). G.M. Nawkar and J.H. Park were supported by a scholarship from the Brain Korea 21 program of the MOEST.

\section{Conflict of Interest}

The authors declare no conflict of interest.

\section{References}

1. Coohill, T.P. Ultraviolet action spectra $(280 \mathrm{~nm}$ to $380 \mathrm{~nm})$ and solar effectiveness spectra for higher plants. Photochem. Photobiol. 1989, 50, 451-457.

2. Frederick, J.E. Ultraviolet sunlight reaching the Earth's surface. A review of recent research. Photochem. Photobiol. 1993, 57, 175-178.

3. Hollosy, F.; Seprodi, J.; Orfi, L.; Eros, D.; Keri, G.; Idei, M. Evaluation of lipophilicity and antitumour activity of parallel carboxamide libraries. J. Chromatogr. B 2002, 780, 355-363.

4. Frohnmeyer, H.; Staiger, D. Ultraviolet-B radiation-mediated responses in plants. Balancing damage and protection. Plant Physiol. 2003, 133, 1420-1428.

5. McKenzie, R.L.; Bjorn, L.O.; Bais, A.; Ilyas, M. Changes in biologically active ultraviolet radiation reaching the Earth's surface. Photochem. Photobiol. Sci. 2003, 2, 5-15.

6. Paul, N.D.; Gwynn, J.D. Ecological roles of solar UV radiation: Towards an integrated approach. Trends Ecol. Evol. 2003, 18, 48-55. 
7. Pyle, J.A. Global Ozone Depletion: Observation and Theory. In Plants and UV-B: Responses to Environmental Change; Lumbsden, P.J., Ed.; Cambridge University Press: Cambridge, UK, 1996; pp. 3-12.

8. McKenzie, R.L.; Aucamp, P.J.; Bais, A.F.; Björn, L.O.; Ilyas, M. Changes in biologically-active ultraviolet radiation reaching the Earth's surface. Photochem. Photobiol. Sci. 2007, 6, 218-231.

9. Herman, J.R. Global increase in UV irradiance during the past 30 years (1979-2008) estimated from satellite data. J. Geophys. Res. 2010, 15, D04203.

10. Ballare, C.L.; Caldwell, M.M.; Flint, S.D.; Robinson, S.A.; Bornman, J.F. Effects of solar ultraviolet radiation on terrestrial ecosystems. Patterns, mechanisms, and interactions with climate change. Photochem. Photobiol. Sci. 2011, 10, 226-241.

11. Ballare, C.L.; Rousseaux, C.M.; Searles, P.S.; Zaller, J.G.; Giordano, C.V.; Robson, M.T.; Caldwell, M.M.; Sala, O.E.; Scopel, A.L. Impacts of solar ultraviolet-B radiation on terrestrial ecosystems of Tierra del Fuego (Southern Argentina). An overview of recent progress. J. Photochem. Photobiol. 2001, 62, 67-77.

12. Caldwell, M.M.; Ballare, C.L.; Bornman, J.F.; Flint, S.D.; Bjorn, L.O.; Teramura, A.H.; Kulandaivelu, G.; Tevini, M. Terrestrial ecosystems increased solar ultraviolet radiation and interactions with other climatic change factors. Photochem. Photobiol Sci. 2003, 2, 29-38.

13. Caldwell, M.M.; Bornman, J.F.; Ballare, C.L.; Flint, S.D.; Kulandaivelu, G. Terrestrial ecosystems, increased solar ultraviolet radiation, and interactions with other climate change factors. Photochem. Photobiol. Sci. 2007, 6, 252-266.

14. Ulm, R.; Baumann, A.; Oravecz, A.; Mate, Z.; Adam, E.; Oakeley, E.J.; Schafer, E.; Nagy, F. Genome-wide analysis of gene expression reveals function of the bZIP transcription factor HY5 in the UV-B response of Arabidopsis. Proc. Natl. Acad. Sci. USA 2004, 101, 1397-1402.

15. Suesslin, C.; Frohnmeyer, H. An Arabidopsis mutant defective in UV-B light-mediated responses. Plant J. 2003, 33, 1-11.

16. Danon, A.; Gallois, P. UV-C radiation induces apoptotic-like changes in Arabidopsis thaliana. FEBS Lett. 1998, 437, 131-136.

17. Danon, A.; Rotari, V.I.; Gordon, A.; Mailhac, N.; Gallois, P. Ultraviolet- C overexposure induces programmed cell death in Arabidopsis, which is mediated by caspase-like activities and which can be suppressed by caspase inhibitors, p35 and Defender against apoptotic Death. J. Biol. Chem. 2004, 279, 779-787.

18. Gao, C.; Xing, D.; Li, L.; Zhang, L. Implication of reactive oxygen species and mitochondrial dysfunction in the early stages of plant programmed cell death induced by ultraviolet-C overexposure. Planta 2008, 227, 755-767.

19. Lytvyn, D.I.; Yemets, A.I.; Blume, Y.B. UV-B overexposure induces programmed cell death in a BY-2 tobacco cell line. Environ. Exp. Bot. 2010, 68, 51-57.

20. Heijde, M.; Ulm, R. UV-B photoreceptor-mediated signaling in plants. Trends Plant Sci. 2012, 17, 230-237.

21. Kami, C.; Lorrain, S. Light-Regulated Plant Growth and Development. In Current Topics in Developmental Biology; Center for Integrative Genomics, University of Lausanne: Lausanne, Switzerland, 2010; Volume 91, pp. 29-65. 
22. Gyula, P.; Scha, E.; Nagy, F. Light perception and signalling in higher plants. Curr. Opin. Plant Biol. 2003, 6, 446-452.

23. Jiao, Y.; Lau, O.S.; Deng, X.W. Light-regulated transcriptional networks in higher plants. Nat. Rev. Genet. 2007, 8, 217-230.

24. Christie, J.M. Phototropin blue light receptors. Annu. Rev. Plant Biol. 2007, 58, 21-45.

25. Demarsy, E.; Fankhauser, C. Higher plants use LOV to perceive blue light. Curr. Opin. Plant Biol. 2009, 12, 69-74.

26. Lin, C.; Shalitin, D. Cryptochome structure and signal transduction. Annu. Rev. Plant Biol. 2003, 54, 469-496.

27. Somers, D.E.; Fujiwara, S. Thinking outside the F-box: Novel ligands for novel receptors. Trends Plant Sci. 2009, 14, 206-213.

28. Franklin, K.A.; Quail, P.H. Phytochrome functions in Arabidopsis development. J. Exp. Bot. 2010, 61, 11-24.

29. Rockwell, N.C.; Su, Y.S.; Lagarias, J.C. Phytochrome structure and signaling mechanisms. Annu. Rev. Plant Biol. 2006, 57, 837-858.

30. Kim, B.C.; Tenessen, D.; Last, R. UV-B-induced photomorphogenesis in Arabidopsis thaliana. Plant J. 1998, 15, 667-674.

31. Boccalandro, H.; Mazza, C.; Mazzella, M.; Casal, J.; Ballare, C. Ultraviolet B radiation enhances a phytochrome-B-mediated photomorphogenic response in Arabidopsis. Plant Physiol. 2001, 126, 780-788.

32. Brosche, M.; Strid, A. Molecular events following perception of ultraviolet-B radiation by plants. Physiol. Plant. 2003, 117, 1-10.

33. Ulm, R.; Nagy, F. Signalling and gene regulation in response to ultraviolet light. Curr. Opin. Plant Biol. 2005, 8, 477-482.

34. Favory, J.J.; Stec, A.; Gruber, H.; Rizzini, L.; Oravecz, A.; Funk, M.; Albert, A.; Cloix, C.; Jenkins, G.I.; Oakeley, E.A.; et al. Interaction of COP1 and UVR8 regulates UVB-induced photomorphogenesis and stress acclimation in Arabidopsis. EMBO J. 2009, 28, 591-601.

35. Kliebenstein, D.J.; Lim, J.E.; Landry, L.G.; Last, R.L. Arabidopsis UVR8 regulates ultraviolet-B signal transduction and tolerance and contains sequence similarity to human regulator of chromatin condensation. Plant Physiol. 2002, 130, 234-243.

36. Brown, B.A.; Cloix, C.; Jiang, G.H.; Kaiserli, E.; Herzyk, P.; Kliebenstein, D.J.; Jenkins, G.I. A UV-B specific signaling component orchestrates plant UV protection. Proc. Natl. Acad. Sci. USA 2005, 102, 18225-18230.

37. Rizzini, L.; Favory, J.J.; Cloiax, C.; Faggionato, D.; Hara, A.O.; Kaiserli, E.; Baumeister, R.; Schafer, E.; Nagy, F.; Jenkins, G.I.; et al. Perception of UV-B by the Arabidopsis UVR8 protein. Science 2011, 332, 103-106.

38. Christie, J.M.; Arvai, A.S.; Baxter, K.J.; Heilmann, M.; Pratt, A.J.; O’Hara, A.; Kelly, S.M.; Hothorn, M.; Smith, B.O.; Hitomi, K.; Jenkins, G.I.; Getzoff, E.D. Plant UVR8 photoreceptor senses UV-B by tryptophan-mediated disruption of cross-dimer salt bridges. Science 2012, 335, 1492-1496.

39. Wu, D.; Hu, Q.; Yan, Z.; Chen, W.; Yan, C.; Huang, X.; Zhang, J.; Yang, P.; Deng, H.; Wang, J.; et al. Structural basis of ultraviolet-B perception by UVR8. Nature 2012, 484, 214-219. 
40. Rice-Evans, C.A.; Miller, N.J.; Papaga, G. Antioxidant properties of phenolic compounds. Trends Plant Sci. 1997, 2, 152-159.

41. Kaiserli, E.; Jenkins, G.I. UV-B promotes rapid nuclear translocation of the Arabidopsis UV-B specific signaling component UVR8 and activates its function in the nucleus. Plant Cell 2007, 19, 2662-2673.

42. Oravecz, A.; Baumann, A.; Mate, Z.; Brzezinska, M.J.; Oakeley, E.J.; Adam, E.; Schafer, E.; Nagy, F.; Ulm, R. CONSTITUTIVELY PHOTOMORPHOGENIC1 is required for the UV-B response in Arabidopsis. Plant Cell 2006, 18, 1975-1990.

43. Brown, B.A.; Jenkins, G.I. UV-B signaling pathways with different fluence-rate response profiles are distinguished in mature Arabidopsis leaf tissue by requirement for UVR8, HY5, and HYH. Plant Physiol. 2008, 146, 276-588.

44. Jiang, L.; Wang, Y.; Li, Q.F.; Bjorm, L.O.; He, J.X.; Li, S.S. Arabidopsis STO/BBX24 negatively regulates UV-B signaling by interacting with COP1 and repressing HY5 transcriptional activity. Cell Res. 2012, 22, 1046-1057.

45. Gruber, H.; Heijde, M.; Heller, W.; Albert, A.; Seidlitz, H.K.; Ulm, R. Negative feedback regulation of UV-B-induced photomorphogenesis and stress acclimation in Arabidopsis. Proc. Natl. Acad. Sci. USA 2010, 107, 20132-20137.

46. Gonzalez Besteiro, M.A.; Bartels, S.; Albert, A.; Ulm, R. Arabidopsis MAP kinase phosphatase 1 and its target MAP kinases 3 and 6 antagonistically determine UV-B stress tolerance, independent of the UVR8 photoreceptor pathway. Plant J. 2011, 68, 727-737.

47. Li, J.; Ou-Lee, T.M.; Raba, R.; Amundson, R.G.; Last, R.L. Arabidopsis flavonoid mutants are hypersensitive to UV-B irradiation. Plant Cell 1993, 5, 171-179.

48. Stracke, R.; Favory, J.J.; Gruber, H.; Bartelniewoehner, L.; Bartels, S.; Binkert, M.; Funk, M.; Weisshaar, B.; Ulm, R. The Arabidopsis bZIP transcription factor HY5 regulates expression of the PFG1/MYB12 gene in response to light and ultraviolet-B radiation. Plant Cell Environ. 2010, $33,88-103$.

49. Xie, Y.; Xu, D.; Cui, W.; Shen, W. Mutation of Arabidopsis HY1 causes UV-C hypersensitivity by impairing carotenoid and flavonoid biosynthesis and the down-regulation of antioxidant defence. J. Exp. Bot. 2012, 63, 3869-3883.

50. Gardner, G.; Lin, C.; Tobin, E.M.; Loehrer, H.; Brinkman, D. Photobiological properties of the inhibition of etiolated Arabidopsis seedling growth by ultraviolet-B irradiation. Plant Cell Environ. 2009, 32, 1573-1583.

51. Degols, G.; Russell, P. Discrete roles of the Spc1 Kinase and the Atf1 transcription factor in the UV response of Schizosacchararomyces peombe. Mol. Cell. Biol. 1997, 17, 3356-3363.

52. Ulm, R. Molecular genetics of genotoxic stress signalling in plants. Topics Curr. Genet. 2003, 4, 217-240.

53. Herrlich, P.; Karin, M.; Weiss, C. Supreme EnLIGHTenment: Damage recognition and signalling in the mammalian response. Mol. Cell. 2008, 29, 279-290.

54. Bartels, S.; Anderson, J.C.; Gonza lez Besteiro, M.A.; Carreri, A.; Hirt, H.; Buchala, A.; Me traux, J.P.; Peck, S.C.; Ulm, R. MAP KINASE PHOSPHATASE1 and PROTEIN TYROSINE PHOSPHATASE1 are repressors of salicylic acid synthesis and SNC1-mediated responses in Arabidopsis. Plant Cell 2009, 21, 2884-2897. 
55. Zhou, C.; Cai, Z.; Guo, Y.; Gan, S. An Arabidopsis mitogen-activated protein kinase cascade MKK9-MPK6 plays a role in leaf senescence. Plant Physiol. 2009, 150, 167-177.

56. Samuel, M.A.; Hall, H.; Krzymowska, M.; Drzewiecka, K.; Hennig, J.; Ellis, B.E. SIPK signalling controls multiple components of harpin-induced cell death in tobacco. Plant J. 2005, 42, 406-416.

57. Adrain, C.; Martin, S.J. The mitochondrial apoptosome: A killer unleashed by the cytochrome seas. Trends Biochem. Sci. 2001, 26, 390-397.

58. Reape, T.J.; McCabe, P.F. Apoptotic-like programmed cell death in plants. New Phytol. 2008, $180,13-26$.

59. Danon, A.; Delorme, V.; Mailhac, N.; Gallois, P. Plant programmed cell death: A common way to die. Plant Physiol. Biochem. 2000, 38, 647-655.

60. Mittler, R.; Lam, E. Sacrifice in the face of foes: Pathogen-induced programmed cell death in plants. Trends Microbiol. 1996, 4, 10-15.

61. Lam, E.; Pontier, D.; del Pozo, O. Die and let live: Programmed cell death in plants. Curr. Opin. Plant Biol. 1999, 2, 502-507.

62. Lam, E.; Pozo, O. Caspase-like protease involvement in the control of plant cell death. Plant Mol. Biol. 2000, 44, 417-428.

63. Wang, H.; Li, J.; Bostock, R.M.; Gilchrist, D.G. Apoptosis: A functional paradigm for programmed cell death induced by a host selective phytotoxin and invoked during development. Plant Cell 1996, 8, 375-391.

64. McCabe, P.F.; Levine, A.; Meijer, P.J.; Tapon, N.A.; Pennell, R.I. A programmed cell death pathway activated in carrot cells cultured at low cell density. Plant J. 1997, 712, 267-280.

65. McCabe, P.F.; Leaver, C.J. Programmed cell death in cell cultures. Plant Mol. Biol. 2000, 44, 359-368.

66. Kawai, M.; Pan, L.; Reed, J.C.; Uchimiya, H. Evolutionally conserved plant homologue of the Bax inhibitor-1 (BI-1) gene capable of suppressing Bax-induced cell death in yeast. FEBS Lett. 1999, 464, 143-147.

67. He, R.; Drury, G.E.; Rotari, V.I.; Gordon, A.; Willer, M.; Farzaneh, T.; Woltering, E.J.; Gallois, P. Metacaspase- 8 modulates programmed cell death induced by ultraviolet light and $\mathrm{H}_{2} \mathrm{O}_{2}$ in Arabidopsis. J. Biol. Chem. 2008, 283, 774-783.

68. Jiang, L.; Wang, Y.; Bjorn, L.O.; Li, S. Arabidopsis radical-induced cell death is involved in UV-B signaling. Photochem. Photobiol. Sci. 2009, 8, 838-846.

69. Ries, G.; Heller, W.; Puchta, H.; Sandermann, H.; Seidlitz, H.K.; Hohn, B. Elevated UV-B radiation reduces genome stability in plants. Nature 2000, 406, 98-101.

70. Hutchinson, F. A review of some topics concerning mutagenesis by ultraviolet light. Photochem. Photobiol. 1987, 45, 897-903.

71. Molinier, J.; Lechner, E.; Dumbliauskas, E.; Genschik, P. Regulation and role of Arabidopsis CUL4-DDB1A-DDB2 in maintaining genome Integrity upon UV stress. PLoS Genet. 2008, 4, e1000093.

72. Liu, Z.; Hossain, G.S.; Islas-Osuna, M.A.; Mitchell, D.L.; Mount, D.W. Repair of UV damage in plants by nucleotide excision repair: Arabidopsis UVH1 DNA repair gene is a homolog of Saccharomyces cerevisiae Rad1. Plant J. 2000, 21, 519-552. 
73. Dubest, S.; Gallego, M.E.; White, C.I. Role of the AtRad1p endonuclease in homologous recombination in plants. EMBO Rep. 2002, 3, 1049-1054.

74. Ahmad, M.; Jarillo, J.A.; Klimczak, L.J.; Landry, L.G.; Peng, T.; Last, R.L.; Cashmore, A.R. An enzyme similar to animal type II photolyases mediates Photoreactivation in Arabidopsis. Plant Cell 1997, 9, 199-207.

75. Nakajima, S.; Sugiyama, M.; Iwai, S.; Hitomi, K.; Otoshi, E.; Kim, S.; Jiang, C.Z.; Todo, T.; Britt, A.B.; Yamamoto, K. Cloning and characterization of a gene (UVR3) required for photorepair of 6-4 photoproducts in Arabidopsis thaliana. Nucleic Acids Res. 1998, 26, 638-644.

76. Zhou, B.B.; Elledge, S.J. The DNA damage response: Putting checkpoints in perspective. Nature 2000, 408, 433-439.

77. Casati, P.; Walbot, V. Gene expression profiling in response to ultraviolet radiation in maize genotypes with varying flavonoid content. Plant Physiol. 2003, 132, 1739-1754.

78. Jiang, L.; Wang, Y.; Bjorn, L.O.; Li, S. UV-B induced DNA damage mediates expression changes of cell cycle regulatory genes in Arabidopsis root tips. Planta 2011, 233, 831-841.

79. Preuss, S.B.; Britt, A.B. A DNA damage induced cell cycle checkpoint in Arabidopsis. Genetics 2003, 164, 323-334.

80. Culligan, K.; Tissier, A.; Britt, A. ATR regulates a G2-Phase cell-cycle checkpoint in Arabidopsis thaliana. Plant Cell 2004, 16, 1091-1104.

81. Garcia, V.; Bruchet, H.; Camescasse, D.; Granier, F.; Bouchez, D.; Tissier, A. AtATM is essential for meiosis and the somatic response to DNA damage in plants. Plant Cell 2003, 15, 119-132.

82. Landry, L.G.; Stapleton, A.E.; Lim, J.; Hoffman, P.; Hays, J.B.; Walbot, V.; Last, R.L. An Arabidopsis photolyase mutant is hypersensitive to ultraviolet-B radiation. Proc. Natl. Acad. Sci. USA 1997, 94, 328-332.

83. Molinier, J.; Ramos, C.; Fritsch, O.; Hohn, B. CENTRIN2 modulates holologous recombination and nucleotide excision repair in Arabidopsis. Plant Cell 2004, 16, 1633-1643.

84. Furukawa, T.; Curtis, M.J.; Tominey, C.M.; Duong, Y.H.; Wilcox, B.W.L.; Aggoune, D.; Hays, J.B.; Britt, A.B. A shared DNA-damage response pathway for induction of stem-cell death by UVB and by gamma irradiation. DNA Repair 2010, 9, 940-948.

85. Sakamoto, A.N.; Lan, V.T.; Puripunyavanich, V.; Hase, Y.; Yokota, Y.; Shikazono, N.; Nakagawa, M.; Narumi, I.; Tanaka, A. A UVB-hypersensitive mutant in Arabidopsis thaliana is defective in the DNA damage response. Plant J. 2009, 60, 509-517.

86. Stein, J.C.; Hansen, G. Mannose induces an endonuclease responsible for DNA laddering in plant cells. Plant Physiol. 1999, 121, 71-80.

87. Houot, V.; Etienne, P.; Petitot, A.S.; Barbier, S.; Blein, J.P.; Suty, L. Hydrogen peroxide induces programmed cell death features in cultured tobacco BY-2 cells, in a dose-dependent manner. J. Exp. Bot. 2001, 52, 1721-1730.

88. Gorczyca, W.; Tuziak, T.; Kram, A.; Melamed, M.R.; Darzynkiewicz, Z. Detection of apoptosis-associated DNA strand breaks in fine-needle aspiration biopsies by in situ end labeling of fragmented DNA. Cytometry 1994, 15, 169-175.

89. Khoroshilova, E.V.; Repeyev, Y.A.; Nikogosyan, D.N. UV photolysis of aromatic amino acids and related dipeptides and tripeptides. Photochem. Photobiol. 1990, 7, 159-172. 
90. Caldwell, C.R. Ultraviolet-induced photodegradation of cucumber (Cucumis sativus L.) microsomal and soluble protein tryptophanyl residues in vitro. Plant Physiol. 1993, 101, 947-953.

91. Fiscus, E.L.; Booker, F.L. Is increased UV-B a threat to crop photosynthesis and productivity? Photosynth. Res. 1995, 43, 81-92.

92. Casati, P.; Walbot, V. Crosslinking of ribosomal proteins to RNA in maize ribosomes by UV-B and its effects on translation. Plant Physiol. 2004, 136, 3319-3332.

93. Kramer, G.F.; Norman, H.L.; Krizek, D.T.; Mirecki, R.M. Influence of UV-B radiation on polyamines, lipid peroxidation and membrane lipids in cucumber. Phytochemistry 1991, 30, 2101-2108.

94. Panagopoulos, I.; Bomman, J.F.; Bjorn, L.O. Effects of ultraviolet radiation and visible light on growth, fluorescence induction, ultra weak luminescence and peroxidase activity in sugar beet plants. Photochem. Photobiol. 1990, 8, 73-87.

95. Mishra, R.K.; Singhal, G.S. Function of photosynthetic apparatus of intact wheat leaves under high light and heat stress and its relationship with peroxidation of thylakoid lipids. Plant Physiol. 1992, 98, 1-6.

96. Murphy, T.M.; Vu, H. Photoactivation of superoxide synthases of the plasma membrane from rose (Rosa damascene Mill.) cells. Photochem. Photobiol. 1996, 64, 106-109.

97. Predieri, S.; Norman, H.A.; Krizek, D.T.; Pillai, P.; Mirecki, R.M.; Zimmerman, R.H. Influence of UV-B radiation on membrane lipid composition and ethylene evolution in (Doyenne D' Hiver) pear shoots grown in vitro under different photosynthetic photon fluxes. Environ. Exp. Bot. 1995, 35, 151-160.

98. Dat, J.; Vandenabeele, S.; Vranova, E.; van Montagu, M.; Inze, D.; van Breusegem, F. Dual action of the active oxygen species during plant stress responses. Cell Mol. Life Sci. 2000, 57, 779-795.

99. Foyer, C.H.; Noctor, G. Redox homeostasis and antioxidant signaling: A metabolic interface between stress perception and physiological responses. Plant Cell 2005, 17, 1866-1875.

100. Zapata, J.M.; Guera, A.; Esteban-Carrasco, A.; Martin, M.; Sabater, B. Chloroplasts regulate leaf senescence: Delayed senescence in transgenic ndhF-defective tobacco. Cell Death Differ. 2005, 12, 1277-1284.

101. Chen, S.R.; Dickman, M.B. Bcl-2 family localize to tobacco chloroplasts and inhibit programmed cell death induced by chloroplast- targeted herbicides. J. Exp. Bot. 2004, 55, 2617-2623.

102. Yao, N.; Eisfelder, B.J.; Marvin, J.; Greenberg, J.T. The mitochondrion-an organelle commonly involved in programmed cell death in Arabidopsis thaliana. Plant J. 2004, 40, 596-610.

103. Wang, X. The expanding role of mitochondria in apoptosis. Genes Dev. 2001, 15, 2922-2933.

104. Wolf, B.B.; Green, D.R. Suicidal tendencies: Apoptotic cell death by caspase family proteinases. J. Biol. Chem. 1999, 274, 20049-20052.

105. Mateo, A.; Muhlenbock, P.; Rusterucci, C.; Chang, C.C.; Miszalski, Z.; Karpinska, B.; Parker, J.E.; Mullineaux, P.M.; Karpinski, S. Lesion simulating disease is required for acclimation to conditions that promote excess excitation energy. Plant Physiol. 2004, 136, 2818-2830.

106. Del Pozo, O.; Lam, E. Caspases and programmed cell death in the hypersensitive response of plants to pathogens. Curr. Biol. 1998, 8, 1129-1132. 
107. Tian, R.; Zhang, G.Y.; Yan, C.H.; Dai, Y.R. Involvement of poly (ADP-ribose) polymerase and activation of caspase-3-like protease in heat shock-induced apoptosis in tobacco suspension cells. FEBS Lett. 2000, 474, 5-11.

108. Uren, A.G.; Rourke, K.; Aravind, L.; Pisabarro, M.T.; Seshagiri, S.; Koonin, E.V.; Dixit, V.M. Identification of paracaspases and metacaspases: Two ancient families of caspase-like proteins, one of which plays a key role in MALT lymphoma. Mol. Cell. 2000, 6, 961-967.

109. Watanabe, N.; Lam, E. Recent advance in the study of caspase-like proteases and Bax inhibitor-1 in plants: Their possible roles as regulator of programmed cell death. Mol. Plant Pathol. 2004, 5, 65-70.

110. Vercammen, D.; van de Cotte, B.; de Jaeger, G.; Eeckhout, D.; Casteels, P.; Vandepoele, K.; Vandenberghe, I.; van Beeumen, J.; Inze, D.; van Breusegem, F. Type II metacaspases Atmc4 and Atmc9 of Arabidopsis thaliana cleave substrates after arginine and lysine. J. Biol. Chem. 2004, 279, 45329-45336.

111. Watanabe, N.; Lam, E. Two Arabidopsis metacaspases AtMCP1 band AtMCP2b are arginine/lysine-specific cysteine proteases and activate apoptosis-like cell death in yeast. J. Biol. Chem. 2005, 280, 14691-14699.

112. Zhang, L.; Xu, Q.; Xing, D.; Gao, C.; Xiong, H. Real-time detection of caspase-3-like protease activation in vivo using fluorescence resonance energy transfer during plant programmed cell death induced by ultraviolet $\mathrm{C}$ overexposure. Plant Physiol. 2009, 150, 1773-1783.

113. Vranova, E.; Inze, D.; van Breusegem, F. Signal transduction during oxidative stress. J. Exp. Bot. 2002, 53, 1227-1236.

114. Apel, K.; Hirt, H. Reactive oxygen species: Metabolism, oxidative stress, and signal transduction. Annu. Rev. Plant Biol. 2004, 55, 373-399.

115. Breusegem, F.V.; Dat, J.F. Reactive oxygen species in plant cell death. Plant Physiol. 2006, 141, 384-390.

116. Mittler, R.; Vanderauwera, S.; Suzuki, N.; Miller, G.; Tognetti, V.B.; Vandepoele, K.; Gollery, M.; Shulaey, V.; van Breusegem, F. ROS signalling: The new wave? Trends Plant Sci. 2011, 16, 300-309.

117. De Tullio, M.C. Antioxidants and redox regulation: Changing notions in a changing world. Plant Physiol. Biochem. 2010, 48, 289-291.

118. Hideg, E.; Vass, I. UV-B induced free radical production in plant leaves and isolated thylakoid membranes. Plant Sci. 1996, 115, 251-260.

119. Kalbina, I.; Strid, A. The role of NADPH oxidase and MAP kinase phosphatase in UV-B-dependent gene expression in Arabidopsis. Plant Cell Environ. 2006, 29, 1783-1793.

120. Mackerness, S.; John, C.F.; Jordan, B.; Thomas, B. Early signaling components in ultraviolet-B responses: Distinct roles for different reactive oxygen species and nitric oxide. FEBS Lett. 2001, 489, 237-242.

121. Pontier, D.; Balague, C.; Roby, D. The hypersensitive response. A programmed cell death associated with plant resistance. C R Acad. Sci. III 1998, 321, 721-734.

122. Jabs, T. Reactive oxygen intermediates as mediators of programmed cell death in plants and animals. Biochem. Pharmacol. 1999, 57, 231-245. 
123. Vacca, R.A.; Valenti, D.; Bobba, A.; Merafina, R.S.; Passarella, S.; Marra, E. Cytochrome c is released in a reactive oxygen species-dependent manner and is degraded via caspase-like proteases in tobacco Bright-Yellow 2 cells en route to heat shock-induced cell death. Plant Physiol. 2006, 141, 208-219.

124. Overmyer, K.; Brosche, M.; Pellinen, R.; Kuittinen, T.; Tuominen, H.; Ahlfors, R.; Keinanen, M.; Saarma, M.; Scheel, D.; Kangasjarvi, J. Ozone-induced programmed cell death in the Arabidopsis radical-induced cell death1 mutant. Plant Physiol. 2005, 137, 1092-1104.

125. Surplus, S.L.; Jordan, B.R.; Murphy, A.M.; Carr, J.P.; Thomas, B.; Mackerness, S. UV-B induced responses in Arabidopsis thaliana: Role of salicylic acid and ROS in the regulation of transcripts and acidic PR proteins. Plant Cell Environ. 1998, 21, 685-694.

126. Mackerness, S. Plant responses to ultraviolet-B (UV-B: 280-320 nm) stress: What are the key regulators? Plant Growth Regul. 2000, 32, 27-39.

127. Demkura, P.V.; Abdala, G.; Baldwin, I.T.; Ballare, C.L. Jasmonate-dependent and independent pathways mediate specific effects of solar ultraviolet $B$ radiation on leaf phenolics and antiherbivore defense. Plant Physiol. 2010, 152, 1084-1095.

128. Demkura, P.V.; Ballare, C.L. UVR8 mediates UV-B induced Arabidopsis defense responses against Botrytis cinerea by controlling sinapate accumulation. Mol. Plant. 2012, 5, 642-652.

129. Mackerness, S.; Surplus, S.L.; Blake, P.; John, C.F.; Buchanan-Wollaston, V.; Jordan, B.R.; Thomas, B. UV-B induced stress and changes in gene expression in Arabidopsis thalaina: Role of signaling pathways controlled by jasmonic acid, ethylene and reactive oxygen species. Plant Cell Environ. 1999, 22, 1413-1424.

130. Lawton, K.A.; Potter, S.L.; Uknes, S.; Ryals, J. Acquired resistance signal transduction in Arabidopsis is ethylene independent. Plant Cell 1994, 6, 581-588.

(C) 2013 by the authors; licensee MDPI, Basel, Switzerland. This article is an open access article distributed under the terms and conditions of the Creative Commons Attribution license (http://creativecommons.org/licenses/by/3.0/). 